Original Research Paper

\title{
Phytomanagement of Heavy Metal Lead by Fodder Grass Lasiurus scindicus in Polluted Soil and Water of Dravyawati River
}

\author{
Parul Sharma and Sonali Pandey \\ Department of Botany, JECRC University, Jaipur, Rajasthan, India
}

\author{
Article history \\ Received: $24-12-2016$ \\ Revised: 06-03-2017 \\ Accepted: 16-03-2017 \\ Corresponding Author: \\ Sonali Pandey \\ Department of Botany, JECRC \\ University, Jaipur, Rajasthan, \\ India \\ Email: drsonali1972@gmail.com
}

\begin{abstract}
Soil and water pollution with heavy metals is a worldwide issue and is still unresolved. Phytoremediation is a new and rising technology that applies plants for cleanup lightly contaminated soils and water. Lasiurus scindicus have been chosen in this work for decontaminating soil and water from heavy metal (lead). This plant was grown in contaminated soil and water over a 105 day pot trial period. Accruement of the heavy metal was studied after 45, 65, 85 and 105 days in leaves and roots by AAS. It was observed that high accumulation level of lead in root after 45 and 65 days. The results conclude that the Lasiurus scindicus has phytoremediation potentiality and could be used in restoring soil polluted with Lead.
\end{abstract}

Keywords: Phytoremediation, Accruement, Metal, AAS

\section{Introduction}

The escalation of industrial, agricultural and activities has increased the risk of soil and water pollution by potentially toxic elements. India is having $2.45 \%$ of land and $4 \%$ of the water resources of the world with $16 \%$ of world population. As the rapid industrial growth is increasing day by day, the rate of generation of waste water and waste soil is also enhancing simultaneously. Most of the research and analysis have shown that the availability of fresh water and soil is reduced on one side and generation of waste water and soil is increasing on another side. Various industries discharged toxic heavy metals directly into the environment. In the industrial area RIICO, Jaipur, many of the chemical and dyes, textile industries are situated. For the treatment of waste water and waste soil collected over their different conventional method of treatment is also regulated, but most of the heavy metal cannot be destroyed by this degradation method (Henry, 2012). Contamination of soil and water by Lead occurs through irrigation with wastewater, disposal of solid wastes, including sewage waste and industrial activity (Aransiola et al., 2013). Heavy metals have shown to very adverse effects on plant growth and soil that leading to decrease in plant productivity (Roy et al., 2005). Soil and water pollution can have a big serious issue for ecosystems because, through the assimilation of these toxic elements by plants, heavy metals adversely effect on plants and animal health (Wuana and Okieimen, 2011). Great efforts have been made to develop strategies for the remediation of this pollution using plants that can decontaminate the soil and water.

Mostly concern heavy metals are Chromium, Mercury, Lead, Cadmium, Copper and Nickel in the environment. Cadmium $(\mathrm{Cd})$ and lead $(\mathrm{Pb})$ heavy metals have high concern because of their highly toxicity and adverse effect on plant functions. Lead is not a require nutrient for plants, most of lead is very easily taken up by plants from the soil and cumulated in root, because only a small amount was transferred to the shoots by roots (Patra et al., 2004). Pb toxicity leads to low the germination, growth of plant, length, dry mass of shoots and roots (Subhashini and Swamy, 2013).

The main problems of ecosystems are increasing with the advancement in new technology. The increased level of lead and other heavy metals, e.g., chromium, lead, cadmium and mercury, in the local water stream is a big problem to ecosystem.

\section{Health Effects}

Lead has been reported as a potential carcinogen in the EPA Toxic Release Inventory (TRI). Inhalation and ingestion are the two modes of exposure and the effects 
of both are the same. When lead enters in the body parts (brain), which may lead to poisoning or even death. The gastrointestinal tract, central nervous system and kidneys, are also affected by the presence of lead. Children exposed to lead are at high risk for impaired development, growth and mental impairment, with children under the age of six being at a more significant risk. Adults, when exposed to lead usually low experience reaction time, loss of memory, nausea, insomnia and weakness of the joints.

Methods of environmental reversion of metalpolluted soils using a green technology have a magnetic increasing interest since it was proposed (Chaney, 1983). It is a technology for regenerating metal polluted soils. So, phytoremediation as a remediation method of polluted soils with cost-effective and very few side effects than physical and chemical approaches (Raskin and Ensley, 2000; Nascimento and Xing, 2006). Phytoextraction appears to be the most bright technique that has received increase getting attention as a green technology for remediation, heavy metals polluted soils (McGrath et al., 2002). It was reported that more than 400 plant species have been recognized to have the potential for soil and water remediation (Robinson et al., 2009). In this study, we aimed at studying the use of Lasiurus scindicus in phytoremediation of soils contaminated with toxic heavy metal lead. Accumulate is largely associated with the availability of metals in soils and water. Some of the plant species are available, which can grow on metal contaminated soils. The Poaceae family grasses are very much studied in the last decade and known to be metal tolerant if they grow on polluted soil and water. The use of green plants as a phytoremediation is a prosperous option, with very minimum negative effects on the soil, have the advantage of removing metals from the soil and is a 50$80 \%$ low cost method comparing with classical methods. The presence of heavy metals in soil has generally synergistic effects on the accumulation of heavy metals in plants, while the macronutrients have, in most of the cases, incompatible effects on the potentiality of heavy metals by grasses.

\section{Materials and Methods}

The experiment was carried out for 105 days pot trial method. Plastic pots of $7 \times 25 \times 11 \mathrm{~cm}$ with double bottoms were used for the experiment. Experiment set up in two ways: Dilution of contaminated soil and dilution of contaminated water. Different dilution of uncontaminated soil $(80,60,40$ and $20 \%$ ) was put into each of the pots (Fig. 2). Initially taken four samples from different sites, but only in two sites found high concentrations of lead in soil and water samples. So experiment done with two sites in the Jaipur industrial area.

\section{Sampling Site Description}

Jaipur (Longitude: $95^{\circ} 24^{\prime} \mathrm{E}$; latitude: $27^{0} 18^{\prime} \mathrm{N}$ ) is a city located in the central part of the Rajasthan is undergoing rapid urbanization and industrialization. Almost in all parts of Jaipur city and adjacent areas, a large number of industries have come up during last two decades. Such area includes Vishwakarma, Sudershanpura, Bais Godown, Jhotwara, Malviya, Sanganer, Sitapura industrial areas, etc., which play a major role in polluting different water resources. Sitapura industrial area was selected for the sampling of research work.

\section{Sample Collection}

Polluted water sample in plastic bottles and polluted soil in plastic bags were collected from different Sitapura industrial areas near (Fig. 1).

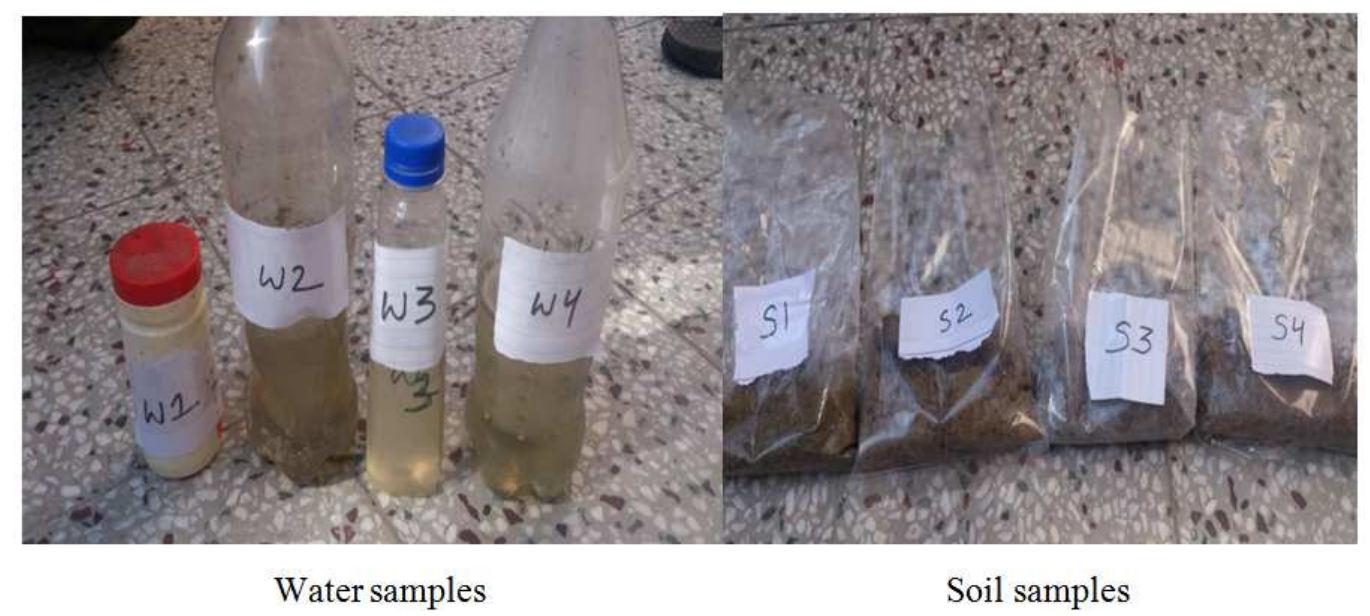

Fig. 1. Collection of water and soil samples 


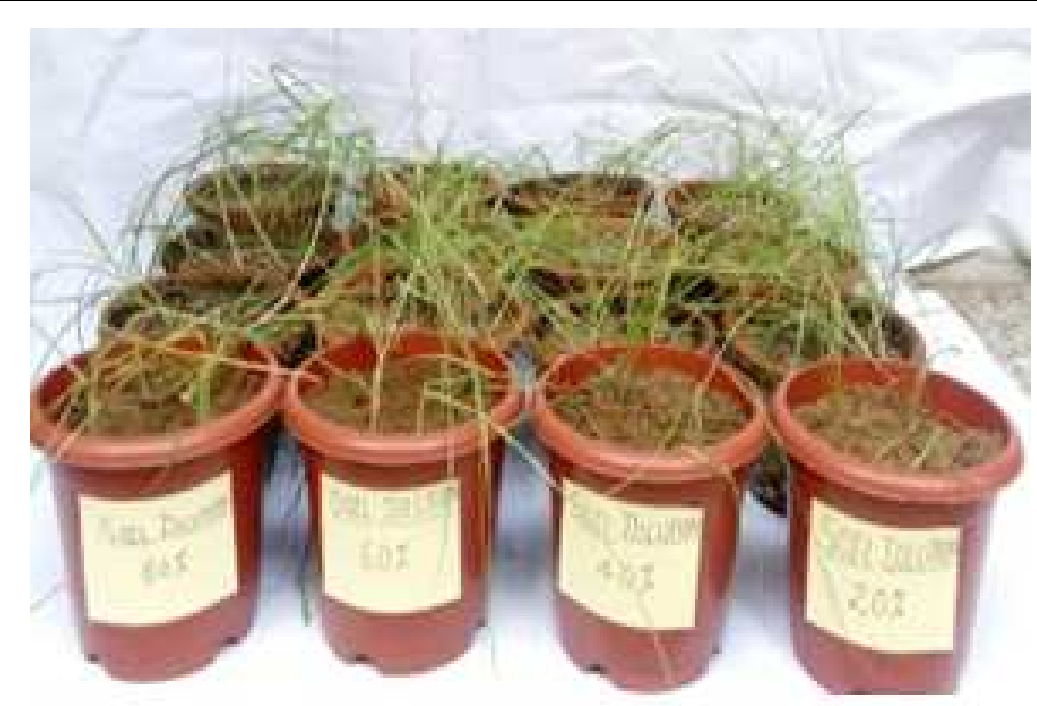

Fig. 2. Sowing of seeds in different concentration of soil and water

The composition of contaminated soil $\mathrm{pH}$ was 9.1-9.5 and nutritional substances included: Potassium - 168-180 $\mathrm{mg} \mathrm{g}^{-1}$, phosphate - 16-15 $\mathrm{mg} \mathrm{g}^{-1}, \mathrm{Cu} 0.26-0.12 \mathrm{ppm}$, Mn 4.22-3.22 ppm, Fe- 4.55-3.22 ppm.

The composition of contaminated water $\mathrm{pH}$ was 7.177.76, Na-13.04-14.78 meq L ${ }^{-1}$, Ca- 5.80-6.00 meq L ${ }^{-1}$, Mg-5.82-6.16. Each pot with soil contained $10 \mathrm{~g}$ of Lasiurus scindicus seeds. Uncontaminated soil was used for growing control plants. Since humidity is the main factor in the growth of plants and the necessary physiological processes, grass plants were watered every 3 days. Those grown in the contaminated soil were watered with different dilution $(80,60,40$ and $20 \%$ ) of polluted water while plants grown in the normal soil were watered with contaminated water. The maintained temperature was $22-24^{\circ} \mathrm{C}$ and the lighting was natural. The experiment lasted 105 days. Firstly uprooted in 45days than every after 20 days were rooted, Lasiurus scindicus prepared for analysis and then analysed. The material was mineralised in the MNIT institute Jaipur; the AAS analysis was carried out at the Department of Material and Research science. Heavy metal lead was identified by a using atomic absorption spectrometer in a flame mode.

Plants were separated into root and leaves and were oven dried at 110C. Soil samples were also oven dried at 110C. 2 gram of each sample were acid digested using HCL and $\mathrm{HNO}_{3}$ (10:3). The samples were kept on a hot plate. After removing from hot plate the solution was cooled and the sample was filtered using Whatman 42 filter paper in $100 \mathrm{~mL}$ cylinder up to $50 \mathrm{~mL}$ so that 50 $\mathrm{mL}$ of each sample was prepared. Water samples were directly subjected to analysis. For the presence of heavy metals in soil and water were tested in MNIT institute Jaipur, presented in table.

\section{Results and Discussion}

Lasiurus scindicus (Sewan grass) species were selected for the present study. Lasiurus scindicus is a perennial grass that can live up to 20 years. It is a bushy, multi-branched desert grass with ascending to erect wiry stems, height up to 1-1.6 m. Leaves are alternate with a thin leaf-blade. The inflorescence is a silky, $10 \mathrm{~cm}$ long bearing hairy spikelets. Fruit is a caryopsis. Lasiurus scindicus is the most common grass in north India. Sewan grass is popular in dry areas of North Africa, Sudan and Sahelian regions, East Africa and Asia. It is majorly growing in the Rajasthan desert area. It is very rich in protein, so use this species use as a fodder. Optimal growth conditions are annual rainfall below $250 \mathrm{~mm}$ on alluvial or light sandy soils with a $\mathrm{pH}$ of 8.5. It is highly tolerable of drought, but should be protected from wind in the early stages of plant. This species is grown in the area adjoining the industries where industrial effluents contaminated with heavy metals is coming to the field so that the present research is undertaken to study the phytotoxic effects of lead on growth parameters and its phytoremediation through Lasiurus scindicus grass.

In the present study the results of phytoremediation experiments (where Lasiurus scindicus seeds are showing in industrial polluted soil and water) indicate a significant recovery of phytotoxicity induced by lead insignificant level. AAS studies also confirm that lead has been absorbed by Lasiurus scindicus where the accumulation is primarily in roots as compared to leaves and this makes useful Lasiurus scindicus for phytostabilization significant that lead is accumulated more roots and is low translocated through the vascular system (Table 1 to 3). Thus Lasiurus scindicus shows as a powerful phytoremediator plant for lead that makes the soil less toxic. 
Parul Sharma and Sonali Pandey / American Journal of Environmental Sciences 2017, 13 (2): 167.171 DOI: 10.3844/ajessp.2017.167.171

$\underline{\text { Table 1. Presence of lead in polluted soil and water in industrial area, Jaipur }}$

\begin{tabular}{|c|c|c|c|c|}
\hline \multirow[b]{2}{*}{ Heavy metal } & \multicolumn{2}{|l|}{ Site I } & \multicolumn{2}{|l|}{ Site II } \\
\hline & Soil $(\mathrm{mg} / \mathrm{kg})$ & Water (ppm) & Soil (mg/kg) & Water (ppm) \\
\hline Lead & 4.28 & 0.682 & 5.82 & 0.721 \\
\hline
\end{tabular}

Table 2. Absorption of lead in plant different soil concentration of industrial area, Jaipur

\begin{tabular}{|c|c|c|c|c|c|c|c|c|}
\hline \multirow[b]{2}{*}{ Different conc. of soil } & \multicolumn{2}{|c|}{45 Days Lead (ppm) } & \multicolumn{2}{|c|}{65 Days Lead (ppm) } & \multicolumn{2}{|c|}{85 Days Lead (ppm) } & \multicolumn{2}{|c|}{105 Days Lead (ppm) } \\
\hline & Root & Leaf & Root & Leaf & Root & Leaf & Root & Leaf \\
\hline \multicolumn{9}{|l|}{ Site-1 } \\
\hline $80 \% \mathrm{WS}+20 \% \mathrm{NS}$ & 0.434 & 0.423 & 0.774 & 0.543 & 0.779 & 0.548 & 0.881 & 0.520 \\
\hline $60 \% \mathrm{WS}+40 \% \mathrm{NS}$ & 0.323 & 0.226 & 0.684 & 0.329 & 0.691 & 0.410 & 0.695 & 0.413 \\
\hline $40 \% \mathrm{WS}+60 \% \mathrm{NS}$ & 0.212 & 0.135 & 0.323 & 0.145 & 0.328 & 0.152 & 0.331 & 0.154 \\
\hline $20 \% \mathrm{WS}+80 \% \mathrm{NS}$ & 0.012 & 0.052 & 0.017 & 0.002 & 0.110 & 0.010 & 0.112 & 0.012 \\
\hline Control & 0.007 & 0.002 & 0.008 & 0.005 & 0.008 & 0.006 & 0.005 & 0.003 \\
\hline \multicolumn{9}{|l|}{ Site- 2} \\
\hline $80 \% \mathrm{WS}+20 \% \mathrm{NS}$ & 0.710 & 0.512 & 0.941 & 0.642 & 0.943 & 0.645 & 0.945 & 0.649 \\
\hline $60 \% \mathrm{WS}+40 \% \mathrm{NS}$ & 0.512 & 0.214 & 0.609 & 0.441 & 0.610 & 0.442 & 0.613 & 0.446 \\
\hline $40 \% \mathrm{WS}+60 \% \mathrm{NS}$ & 0.503 & 0.014 & 0.510 & 0.309 & 0.511 & 0.312 & 0.512 & 0.318 \\
\hline $20 \% \mathrm{WS}+80 \% \mathrm{NS}$ & 0.359 & 0.009 & 0.443 & 0.145 & 0.445 & 0.148 & 0.446 & 0.150 \\
\hline Control & 0.008 & 0.003 & 0.006 & 0.003 & 0.005 & 0.002 & 0.003 & 0.001 \\
\hline
\end{tabular}

WS $=$ Waste Soil, NS $=$ Normal Soil

Table 3. Absorption of Lead in plant different water concentration of industrial area, Jaipur

\begin{tabular}{|c|c|c|c|c|c|c|c|c|}
\hline \multirow[b]{2}{*}{ Different conc. of water } & \multicolumn{2}{|c|}{45 Days Lead (ppm) } & \multicolumn{2}{|c|}{65 Days Lead (ppm) } & \multicolumn{2}{|c|}{85 Days Lead (ppm) } & \multicolumn{2}{|c|}{105 Days Lead (ppm) } \\
\hline & Root & Leaf & Root & Leaf & Root & Leaf & Root & Leaf \\
\hline \multicolumn{9}{|l|}{ Site-1 } \\
\hline $80 \% \mathrm{WW}+20 \% \mathrm{NW}$ & 0.212 & 0.125 & 0.510 & 0.277 & 0.515 & 0.279 & 0.520 & 0.281 \\
\hline $60 \% \mathrm{WW}+40 \% \mathrm{NW}$ & 0.123 & 0.092 & 0.512 & 0.308 & 0.519 & 0.310 & 0.522 & 0.311 \\
\hline $40 \% \mathrm{WW}+60 \% \mathrm{NW}$ & 0.052 & 0.072 & 0.211 & 0.012 & 0.213 & 0.018 & 0.215 & 0.020 \\
\hline $20 \% \mathrm{WW}+80 \% \mathrm{NW}$ & 0.024 & 0.042 & 0.178 & 0.005 & 0.179 & 0,010 & 0.181 & 0.011 \\
\hline Control & 0.004 & 0.002 & 0.006 & 0.001 & 0.007 & 0.001 & 0.003 & 0.001 \\
\hline \multicolumn{9}{|l|}{ Site- 2} \\
\hline $80 \% \mathrm{WW}+20 \% \mathrm{NW}$ & 0.509 & 0.321 & 0.721 & 0.523 & 0.723 & 0.525 & 0.725 & 0.529 \\
\hline $60 \% \mathrm{WW}+40 \% \mathrm{NW}$ & 0.423 & 0.112 & 0.623 & 0.329 & 0.625 & 0.331 & 0.629 & 0.335 \\
\hline $40 \% \mathrm{WW}+60 \% \mathrm{NW}$ & 0.314 & 0.062 & 0.607 & 0.334 & 0.608 & 0.335 & 0.610 & 0.339 \\
\hline $20 \% \mathrm{WW}+80 \% \mathrm{NW}$ & 0.129 & 0.002 & 0.321 & 0.015 & 0.323 & 0.019 & 0.325 & 0.022 \\
\hline Control & 0.005 & 0.002 & 0.003 & 0.003 & 0.003 & 0.002 & 0.001 & 0.001 \\
\hline
\end{tabular}

$\mathrm{WW}=$ Waste Water, $\mathrm{NW}=$ Normal Water

As a result, phytotoxicity of lead on growth parameters has been drastically decreased. The mechanisms behind this hyperaccumulation and detoxification include chelation to organic acids (Nehnevajova et al., 2005) or proteins (Oven et al., 2002; Martens et al., 1996) or it may be due to its larger biomass apart from the stronger metal uptake ability. The fact that Lasiurus Scindicus can live some 50 years. Thus, the present study shows that the Lasiurus Scindicus grass may be used as potential phytoremediator plant at industrial sites contaminated with lead and try to make this species an efficient, enduring, low cost and long term remedial option for phytoremediation.

The chemistry of metal accumulation with soil is the most criterion to the phytoremediation concept. Soil $\mathrm{pH}$ affects metal bioavailability as well as metal accumulate by the roots (Brown et al., 1995). Sanders (1983) reported that the higher availability of heavy metals in soil that decreases $\mathrm{pH}$ within the $\mathrm{pH}$ of normal agricultural soils. The higher $\mathrm{pH}$ values of soils could have signified for a low transfer of heavy metals from contaminated soil to plants. Chaney and Giordano (1977) reported that soils with high Cation Exchange Capacity (CECs) could absorb large amounts of heavy metals than soil with low CEC.

\section{Conclusion}

Based on the results of the present work:

- Lead causes negative effects on growth and metabolism of Lasiurus scindicus. This is observed from the 105 days experiment work

- Lasiurus scindicus is more receptive to lead toxicity 
- A significant result was found that lead accumulation in Lasiurus scindicus (mostly in its roots) confirming its potentiality as a phytoremediator and due to polluted soil $\mathrm{pH}$ high amount of lead accumulated in root compare to leaf. Therefore accumulation is stabilized in root.

\section{Acknowledgement}

The author is thankful to MNIT Jaipur for providing technical assistance and JECRC University for research work.

\section{Author's Contributions}

Parul Sharma: Participated in all experiments, coordinated data analysis and contributed to the writing of the manuscript.

Sonali Pandey: Designed the research plan.

\section{Ethics}

This article is original and contains unpublished material. The corresponding author confirms that all of the other authors have read and approved the manuscript and no ethical issues involved.

\section{References}

Henry, J.R., 2012. An overview of the phytoremedation of lead and mercury.

Aransiola, S.A., U.J.J. Ijah and O.P. Abioye, 2013. Phytoremediation of lead polluted soil by Glycine max L., Applied Environ. Soil Sci., 2013: 631619-631625. DOI: 10.1155/2013/631619

Brown, S.L., R.L. Chaney, J.S. Angle and A.J.M. Baker, 1995. Zinc and cadmium uptake by hyperaccumulator Thlaspi caerulescens and metal tolerant Silene vulgaris grown on sludge-amended soils. Environ. Sci. Technol., 29: 1581-1585.

DOI: $10.1021 / \mathrm{es} 00006 \mathrm{a} 022$

Chaney, R.L., 1983. Plant Uptake of Inorganic Waste Constituents. In: Land Treatment of Inorganic Wastes, Parr, J.F., P.B. Marsch and J.S. Kla (Eds.), Noyes Data, ParkRidge, pp: 50-76.

Chaney, R.L. and P.M. Giordano, 1977. Microelements as Related to Plant Deficiencies and Toxicities. In: Soils for Management of Organic Wastes and Wastewaters, Elliott, L.F. and F.J. Stevenson (Eds.), American Society of Agronomy, Madison, WI, pp: 235-279.

Martens, S.N., B.W. Stephens and M.A. Grusak, 1996. Identification of an iron translocator/putativesignal molecule in the phloem of higher plants. Physiol. S, 111: 302-302.
McGrath, S.P., F.J. Zhao and E. Lombi, 2002. Phytoremediation of metals, metalloids and radionuclides. Adv. Agronomy, 75: 1-56. DOI: 10.1016/S0065-2113(02)75002-5

Nascimento, C.W.A. and B. Xing, 2006. Phytoextraction: A review on enhanced metal availability and plant accumulation. Scientia Agricola, 63: 299-311. DOI: $10.1590 / \mathrm{S} 0103-90162006000300014$

Nehnevajova, E.H., R. Federer, G. Erismann, K.H. Schwitzguebel and J. Paul, 2005. Screening of sunflower cultivars for metal phytoextraction in a contaminated field prior to mutagenesis. Int. J. Phytoremed., 7: 337-349.

DOI: $10.1080 / 16226510500327210$

Oven, M., E. Grill, A. Golan-Goldhirsh, T.M. Kutchan and H.Z. Meinhart, 2002. Increase of free cysteine and citric acid in plant cells exposed to cobalt ions. Phytochemistry, 60: 467-474. DOI: 10.1016/S0031-9422(02)00135-8

Patra, M., N. Bhowmik, B. Bandopadhyay and A. Sharma, 2004. Comparison of mercury, lead and arsenic with respect to genotoxic effects on plant systems and the development of genetic tolerance. Environ. Exp. Bot., 52: 199-223.

DOI: 10.1016/j.envexpbot.2004.02.009

Raskin, I. and B.D. Ensley, 2000. Phytoremediation of Toxic Metals: Using Plants to Clean up the Environment. 1st Edn., John Wiley and Sons, Inc., New York, ISBN-10: 0471192546, pp: 304.

Robinson, B.H., G. Banuelos, H.M. Conesa, M.W.H. Evangelou and R. Schulin, 2009. The phytomanagement of trace elements in soil. Critical Rev. Plant Sci., 28: 240-266.

DOI: $10.1080 / 07352680903035424$

Roy, S., S. Labelle and P. Mehta, 2005. Phytoremediation of heavy metal and PAHcontaminated brownfield sites. Plant Soil, 272: 277-290. DOI: 10.1007/s11104-004-5295-9

Sanders, J.R., 1983. The effect of $\mathrm{pH}$ on the total and free ionic concentrations of mnganese, zinc and cobalt in soil solutions. J. Soil Sci., 34: 315-323. DOI: 10.1111/j.1365-2389.1983.tb01037.x

Subhashini, V. and A.V.V.S. Swamy, 2013. Phytoremediation of $\mathrm{Pb}$ and $\mathrm{Ni}$ contaminated soils using Catharanthus roseus (L.). Univ. J. Environ. Res. Technol., 3: 465-472.

Wuana, R.A. and F.E. Okieimen, 2011. Heavy metals in contaminated soils: A review of sources, chemistry, risks and best available strategies for remediation. Int. Scholarly Res. Netw. Ecol., 2011: 402647-402668. DOI: $10.5402 / 2011 / 402647$ 